Journal of Development and Communication Studies, Vol. 8. No. 1, January -June, 2021 ISSN (Online \& Print): 2305-7432. http://www.devcomsjournalmw.org

\title{
COVID-19 Pandemic: Questioning Conspiracy Theories, Beliefs or Claims that Have Potential Negative Impact on Public Health Interventions and Proposal for Integrated Communication and Information Dissemination Strategies (ICIDS)
}

Aceme Nyika, Graduate Support, Research and Innovation Department, University of Pretoria, South Africa. Email: Aceme.Nyika@up.ac.za or Nyikaa@yahoo.com, Geraldine Taponeswa Nyika, Department of Information Science, College of Human Sciences, University of South Africa. Email: geralnyika@gmail.com, Jeffrey Tonderai Nyika, Department of Industrial and Systems Engineering, Faculty of Engineering, Built Environment and Information Technology, University of Pretoria, South Africa. Email: jeffnyika@gmail.com, Jeremy Tashinga Nyika, Department of Informatics, Faculty of Engineering, Built Environment and Information Technology, University of Pretoria, South Africa. Email: jeremynyika@gmail.com \& Trenah Nyika, College of Economic and Management Sciences, University of South Africa, South Africa. Email: trenahnyika@gmail.com

\begin{abstract}
The COVID-19 outbreak that started in Wuhan, China, in December 2019 spread across the world causing a pandemic that infected and killed thousands of people globally. Countries made frantic efforts to put in place measures to curb the spread of the viral infections. The measures included social distancing, regular washing of hands with soap, applying sanitizers to hands and surfaces, use of personal protective equipment, screening, testing, isolation of suspected cases, quarantine of cases, lockdowns, treatment of cases and controlled burial of deceased cases.

Almost all affected countries experienced four main hindrances to their efforts to control the COVID-19 pandemic; (i) challenges in implementing preventative measures effectively, (ii) health care delivery systems that could not cope with the pandemic, (iii) limited resources, and (iv) negative socio-economic impact caused by the pandemic. One of the challenges that hindered efforts to prevent the spread of the pandemic or to manage it are various conspiracy theories, beliefs, and or unproven claims, some of which are contradictory, that were circulated across the world.
\end{abstract}


This article gives an overview of the covid-19 pandemic, some conspiracy theories, beliefs and claims that were circulated as unofficial information, and questions the unofficial information. The article ends with an outline of some potential negative impact of conspiracy theories, beliefs and claims on public health interventions aimed at controlling the pandemic. In order to counter disinformation and misinformation, the article recommends the establishment of well-coordinated Integrated Communication and Information Dissemination Strategies (ICIDS) at global, continental, regional and national levels.

Keywords: COVID-19 pandemic, conspiracy theories, beliefs, claims, public health interventions

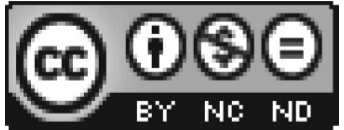

(C) 2020. The authors. This work is licensed under the Creative Commons Attribution 4.0 International License (CC-By-NC-ND). Users may freely share and redistribute this work provided that the author and the Journal of

Development and Communication Studies are fully acknowledged. Users may not tweak or remix and offer this work for sale. The full license may be accessed at https://creativecommons.org/licenses/by-nc-nd/4.0/

To cite this article: Nyika, A., Nyika, G.T., Jeffrey Tonderai Nyika, J.T. \& Nyika, T. (2021). COVID-19 Pandemic: Questioning Conspiracy Theories, Beliefs or Claims that Have Potential Negative Impact on Public Health Interventions and Proposal for Integrated Communication and Information Dissemination Strategies (ICIDS). Journal of Development and Communication Studies, 8(1), 1-21 https://dx.doi.org/10.4314/jdcs.v8i1.1

\section{Introduction}

Several pandemics have occurred previously, although they are relatively rare compared with epidemics. Bacterial and viral pathogens can cause pandemics, but viral pathogens that can be transmitted through droplets or aerosols generated by sneezing or coughing tend to spread faster than bacteria. The 'Spanish' influenza H1N1 pandemic, which started in 1918 and occurred in three waves, caused an estimated global mortality of around 50 million people (Mueller and Johnson, 2002; Taubenberger and Morens, 2006; Trilla, Trilla and Daer, 2008). In 1957, another influenza pandemic, caused by influenza strain H2N2, started in Asia and spread to many countries (Kilbourne, 2006). Another influenza pandemic started in Hong Kong in 1968 and was caused by the strain H3N2 (Kilbourne, 2006). In April 2009 there was an outbreak of a swine-origin influenza virus (S-OIV), A (H1N1), in Mexico and the USA, which quickly spread globally and was declared a pandemic by the WHO by June 2009 (Girard et al., 2010). 
In December 2019 a pandemic was caused by a strain of corona viruses which the WHO has named COVID-19. Corona viruses are a family of RNA viruses that belong to the phylogenetic order Nidovirales, Coronaviridae family, and Coronavirus genus (Perlman and Netland, 2009). Coronaviruses can infect and cause illness in humans, other mammals and birds (Spaan, Cavanagh and Horzinek, 1988). Research has been conducted on many corona viruses, including human corona viruses (HCV), mouse hepatitis virus (MHV), chicken infectious bronchitis virus (IBV), bovine corona virus (BCV) and feline infectious peritonitis virus (FIPV), (McNulty et al., 1984; Spaan, Cavanagh and Horzinek, 1988; Haring and Perlman, 2001; Cavanagh, 2007; Pedersen, 2009). The human corona viruses include NL63 (HCoV-NL63), HCoV-HKU1, severe acute respiratory syndrome (SARS-CoV), the middle east respiratory syndrome (MERS) and Covid-19 (van der Hoek, 2007; Hilgenfeld and Peiris, 2013; WHO, 2020; Xu et al., 2020).

The COVID-19 pandemic started in Wuhan, the capital of China's Hubei province. The first report of the virus was on 31 December 2019 when the WHO China Country Office was notified of pneumonia cases of unknown cause detected in Wuhan City (WHO, 2020). Globally, there were 17,794,549 cases, 11,186,375 recoveries and 683,798 deaths by 01 August 2020 (Worldometer, 2020).

\section{Measures to Curb the Covid-19 Pandemic}

Most countries restricted movement of people in cities, regions or whole countries through lockdowns aimed at preventing people who may be infected from potentially spreading infection by moving from one place to another. Control measures included social distancing, regular washing of hands with soap, sanitizing surfaces, use of personal protective equipment, screening, testing, isolation of suspected cases, quarantine of cases, treatment of cases, and immediate and strictly controlled burial of deceased cases. Government authorities declared state of disaster or state of emergency which provided legal framework that enabled the states to restrict people's movements. State of disaster or emergency also enabled governments to ban social gatherings and to enforce social distancing.

Travelling into and out of countries was banned during lockdowns. Personal protective equipment such as masks, respirators, gloves and protective clothing were used for protection, especially by health care workers who work in hospitals, clinics and screening or testing centres. People who may have been exposed to infection through contact with those infected or have recently travelled to high risk areas or countries were quarantined for at least 14 days. Those that tested positive were isolated in designated places that were set up to prevent spread of infection. Other measures have to do with hygiene. They include regular hand-washing with clean water and soap, disinfecting hands with sanitisers and disinfecting public places. 


\section{Some Conspiracy Theories Surrounding COVID-19 Pandemic and Some Pertinent Questions}

Many conspiracy theories and fake news about the covid-19 pandemic, some of which contradictory to each other, were spread widely and speedily across the globe to an extent that they were referred to as an 'infodemic' (Mejova and Kalimeri, 2020). These conspiracy theories were spread through platforms like WhatsApp, Facebook and Tweeter where people chime in their opinions which they state as facts. Unfortunately, some influential individuals like religious leaders, community leaders, celebrities and politicians participated in spreading the conspiracy theories or fake news, thus fueling the 'infodemic'. In this paper, an overview of some conspiracy theories, beliefs and claims about the covid-19 pandemic is given, not as an attempt at providing an exhaustive list of all conspiracy theories, beliefs and claims that have cropped up, but as a way of building an argument that they are a phenomenon that can significantly hamper efforts to contain pandemics to an extent that players and stakeholders involved in fighting disease pandemics need to develop multi-facetted mechanisms of mitigating the phenomenon. The article proposes that Integrated Communication and Information Dissemination Strategies (ICIDS) should be developed to mitigate the negative impact of this phenomenon.

\section{Radiation from 5G Transmission Caused COVID-19 Pandemic}

One conspiracy theory that was circulated globally was that radiation emitted by $5 \mathrm{G}$ transmitters caused people to be ill and some of them to die. However, the mobile wireless technology has developed from 1G through 2G and 3G to 4G (Levin, 2017) without any conclusive scientific evidence of detrimental side effects of radiation on the health of humans. Before the development of 1G, there existed telephone technology called 'Zero Generation' technology (0G), which enabled only a few channels to be used (Reddy, Jaswanth and Pramod, no date). These technologies work by transmitting information through radio waves without the use of wires.

In 1979, 1G was introduced and was used on analog technology (Reddy, Jaswanth and Pramod, no date). However, its main shortcomings were its inability to operate between different countries and lack of security between the sender and receiver of information. To circumvent shortcomings of 1G, in 1991 2G was developed and it was based on digital technology (Levin, 2017). It enabled texting of text, pictures and MMS. In addition, encryption and decryption enhanced security.

Subsequently, 3G technology, which was faster than 2G and enabled downloading of high data multimedia files, was developed in 2001. The next generation was $4 \mathrm{G}$ which enabled higher download speeds than 3G. However, for real time functionalities, $4 \mathrm{G}$ still has some limitations hence the development of $5 \mathrm{G}$ which will have a latency of almost zero, and thus enabling it to handle real time 
functionalities without any 'delays' caused by buffering. After 5G, there will be more generations like 6G and so on (sharma, 2013; Kalbande et al., 2019; Jacob, 2020).

The 5G-based conspiracy theory claims that there is radiation from the $5 \mathrm{G}$ transmitters which makes people sick leading to some of them dying. As of December 2019, 5G transmitters had not been installed in all countries and across all continents. Does this mean that the so called 5G radiation came from wherever some 5G transmitters were installed and reached all parts of the world where $5 \mathrm{G}$ transmitters had not been installed? If that was the case, how come the radiation seemed to be selective, making some people sick while others in the same community and same location did not fall sick? Why were animals not affected by the $5 \mathrm{G}$ radiation as it travelled across the world? Does this mean that the $5 \mathrm{G}$ radiation has no effect on vegetation, which did not seem to get 'scorched' by the radiation? When the COVID19 pandemic is eventually over and 5G is still there, what would be the explanation for the $5 \mathrm{G}$ radiation not continuing to cause illness in people? When mobile wireless technologies have gone beyond $5 \mathrm{G}$ and reached $6 \mathrm{G}, 7 \mathrm{G}$, and so on, but without any pandemic associated with them, what explanation for the absence of pandemics would the peddlers of this conspiracy theory give?

\section{The Mark of the Beast Conspiracy Theory}

The biblical Mark of Beast was used as a basis for some conspiracy theories. According to the Christian Bible, in the $13^{\text {th }}$ chapter of the book of Revelation, John saw two beasts $(19,20)$. The first beast was like a leopard and it came out of the sea (Wong, 2003). It had feet that looked like those of a bear, a mouth that looked like a lion, seven heads and ten horns. The second beast had two horns like a lamb (Koester, 2017). This beast forced people from diverse backgrounds the world over to receive a mark on their right hand or on their forehead, such that no one could buy or sell unless they had this mark, which was the number 666 representing its name (Koester, 2017).

One conspiracy theory about the COVID-19 pandemic is that there are no biological COVID-19 viruses, but that what was experienced globally is the effect of the Mark of the Beast. The conspiracy theory posits that all the suffering that people experienced were performances by the beast that were meant to deceive people and make them obey, follow and worship the beast. Once people had given in to the beast, the beast would then introduce a mark on the people that would enable the beast to control all aspects of live, including commercial activities. The conspiracy theory claims the mark of the beast, the number 666, will be introduced into people through injections disguised as treatment for illness (COVID-19 illness) or vaccination to prevent COVID-19 illness. In other words, the conspiracy theory claims that the mark of the beast caused what is said to be the COVID-19 pandemic with the intention of making people accept to be injected with the mark of the beast disguised as treatment or vaccination. Once injected with the mark of the beast, people would be controlled, 
even in terms of selling and buying commodities in the markets. That way, the whole world would eventually be ruled by one ruler using one currency.

The conspiracy theory does not explain why people who had not been injected with anything fell sick and some of them died during the pandemic. What sort of people were protected from the beast during the covid-19 pandemic.......'true Christians'? If so, does that imply that Christians who may have succumbed to the pandemic, including some Christian leaders, were not true Christians? Why did the whole pandemic start from certain parts of the world, and then spread to other parts? Who or what was the beast that people were forced to obey and worship, and how were they supposed to do that practically? Regarding the COVID-19 pandemic, were the beasts some supernatural and spiritual entities or were they natural animals or humans? In the same vein, was the chip with the number 666 a supernatural or spiritual item or was it an actual tangible chip created in an actual laboratory by natural humans? When the pandemic was over and there was no single ruler of the whole world and no single global currency, what would be the explanation? Questions about linking the mark of the beast and the number of the beast, 666, with modern technology in general have been raised before (Michael, 2010).

\section{Conspiracy Theories Centred on Electronic Chips}

Some people claimed that there are influential people who are looking to use the COVID-19 pandemic as an opportunity to impose tracking technology on people through vaccination. One claim stated that a tracking chip would be inserted into people's bodies simultaneously with and through a vaccine without people's knowledge or consent (Burnard and Richards, 2020). Another claim stated that a chip in the form of a nano-tattoo would be implanted in people's skin at vaccination supposedly for precision medicine yet the real intentions would not be as noble(Michael, 2010; Koester, 2017). Though the theories differ in terms of the claimed implementation approach and the type of chips, they converge on the claimed purpose of the chips; infringing on people's right to privacy through tracking and surveillance technology.

Use of chips is not new. Applications of the chips include automotive electronics, televisions, computer processors, microwaves, gaming consoles, memory devices, cameras, smartphones, aeroplanes, space crafts, drones, robotic arms, military equipment, medical equipment and even calculators (YODER, 1985; Alexandrov et al., 2000; Knapp et al., 2012; Psychalinos and Elwakil, 2017). Though not new, an area of application which has recently sparked debate is microchip implants for humans. As far back as 2008, microchip implants were considered as straightforward procedures and some examples of application include the installation of pacemakers in humans and a great number of other medical innovations for prosthesis (Michael, Michael and Ip, 2008). Farra et al. (Farra et al., 2012) conducted 
the first in-human testing of a wirelessly controlled drug delivery microchip and Koch et al. (Koch et al., 2008) showcased successful results of a study on a completely retinal prosthesis in 6 blind humans. There has also been on-going research into the ethical and health issues surrounding microchip implants (Foster and Jaeger, 2008; Achille, Perakslis and Michael, 2012; Stingl et al., 2013; Werber, Baggia and Znidarsic, 2018).

Regarding the conspiracy theory, it is not clear whether or not the theory acknowledged COVID-19 as a real biological disease outbreak that the powers that be merely wanted to take advantage of in order to inject their chip into people. Since it would be possible to detect a chip if it was in a human body, is there any evidence of microchips that were inserted into people through vaccines during the COVID-19 pandemic? Is there any working relationship between the organisations conducting research on corona virus to develop effective vaccines and those conducting research on the development of chip implants?

Since there are several different research groups conducting research on vaccines in different parts of the world, does it mean that all these research groups are in a network with the powers that be who developed the chip to be used to control people secretly? If these chips contain tracking technology, which organisations would be tracking and storing the data recorded from the chips and how would they benefit from such data collected from all continents?

\section{Event 201 Conspiracy Theory}

In October 2019 a coronavirus pandemic simulation exercise, referred to as 'Event 201', was conducted in New York, USA, in order to assess the level of preparedness for a real pandemic (Pearce, 2020). One conspiracy theory is that the aim of Event 201 was to plan the COVID-19 pandemic which was deliberately implemented in December 2019. The event was organised by the Johns Hopkins Centre for Health Security and was attended by various stakeholders or players that included representatives of the health sector, the private business sector, politicians, governments, Centers for Disease Control and Prevention and the World Health Organisation. A hypothetical pandemic was used to explore and learn potential impact of such a pandemic and how various global players should react. Overall, the simulation revealed huge preparedness gaps. Thus, the aim of event 201 was to enhance preparedness for real pandemics.

Event 201 was not the first disease outbreak simulation to be organised by the Johns Hopkins Centre for Health Security; it was the $4^{\text {th }}$ simulation event (Pearce, 2020). In 2001 a smallpox outbreak was simulated; the simulation was referred to as the 'Dark Winter'. The second one was the Atlantic Storm that was conducted in 2005. The third simulation was the 'Clade X' exercise that was done in May 2018.

Is it in line with its roles and duties for the Johns Hopkins Center for Health Security to be organising such disease outbreak simulations? If the aim of the exercise 
was to develop a harmful pathogen and cause global outbreak, why would the exercise be done openly? If that was the case, does that imply that China was part of the plan? How would those who deliberately caused the pandemic benefit from the destruction of human lives and economies that it caused?

\section{Conspiracy Theories Based on Vaccines}

Some conspiracy theories claim that people were injected with some harmful coronaviruses created in labs. Some of these theories have revealed misconceptions of what vaccines are and how they get licensed for use by the public. It is therefore important to briefly tackle these issues before touching on some conspiracy theories based on vaccines.

In simple terms, a vaccine is a weakened pathogen (such as bacteria or viruses), or part of a pathogen, that is used to activate the immune system of a person or animal so that it is ready and strong enough to fight the real 'unweakened' pathogen if the vaccinated person or animal is exposed to it. Thus, a vaccine against coronavirus infection must have weakened coronavirus or some parts of the virus. For instance, Bacille Calmette-Guérin (BCG) is a weakened Mycobacterium tuberculosis, the bacteria that cause tuberculosis (TB), and has been used for over 90 years to vaccinate over 4 billion people in countries where TB is endemic (Luca and Mihaescu, 2013). Diphtheria-Tetanus-Acellular Pertussis vaccine (DTPa) contains toxoids of the bacteria that cause the diseases diptheria, tetanus and pertussis while DTPw contains whole attenuated cells of pertussis bacteria instead of its toxoids (Bogaerts et al., 1996).

Vaccines can be for preventing a disease (preventive vaccines) or for treating a disease (therapeutic vaccines). Any form of vaccine for humans has to be tested in animals first, and if it is safe and shows potential to be effective, it is then tested in humans. The first test in humans, called phase 1 clinical trial, is aimed at making sure that the vaccine is not harmful to humans. Any research that involves humans must be reviewed by relevant Ethics Committees in the country where the research is conducted. Few people, around 30, are enrolled in Phase 1 clinical trial after they are informed that it is a trial aimed at testing a new vaccine and they have given voluntary informed consent.

If a vaccine candidate is shown to be safe in phase 1 clinical trial, it is then tested in relatively bigger sample size of people in phase 2 clinical trials. Vaccines can only be approved by national regulatory authorities after phase 3 clinical trials have shown that they are effective in preventing the disease for which they are intended. Thus, vaccines cannot be tested secretly because firstly the clinical trials have to be approved by Ethics Committees before they are conducted and secondly the national regulatory authorities scrutinise the results obtained from the clinical trials before approving the vaccine for use in their respective countries. 
The conspiracy theories about vaccines are linked to other conspiracy theories in one way or another. There are several versions of the vaccine conspiracy theory. Version 1 is that a vaccine containing a chip was injected into people in order to ensure that the global population can be controlled by some powers that be through the chip. The chip is said to contain information that enables the powers that be to control all the people injected with the chip. According to the theory, it is the chip-containing vaccine which makes people sick and kills some of them. Does this imply that governments and health authorities across the world received the chip-containing vaccine and then injected it into people in their countries? What caused people who had never been injected with anything to fall sick in different parts of the world?

Version 2 of the vaccines conspiracy theory is that harmful, biological coronaviruses were created in a laboratory under the pretext that they were vaccines and they were injected into people causing them to be ill. The theory is that the vaccines contained man-made coronaviruses or modified coronaviruses that were deliberately made harmful to the health of humans. What was the aim of harming ordinary people through the man-made coronaviruses? Who are the powers that be that made the harmful viruses and how did they benefit from the illness and death of thousands of people?

Version 3 could be considered to be a combination of conspiracy theories versions 1 and 2. It argues that a harmful man-made or lab-modified coronavirus (more like conspiracy theory version 2 ) was used to make people sick in order to make them so vulnerable that they would easily accept a vaccine that contains a chip (conspiracy version 1). In other words, a harmful coronavirus created in a lab by the powers that be was injected into people globally so that people, governments, health authorities and other players or stakeholders would easily accept a chip-containing vaccine that was made by the same powers that be.

Did countries across the world first receive deliveries of any forms of coronaviruses that they injected into their own people before people started falling sick and some dying? Were the coronaviruses delivered to various countries before or after people started falling sick in large numbers? Is the implication that the chipcontaining vaccine and the lab-made or lab-modified coronaviruses were developed and tested secretly without any approval from Ethics Committees and Regulatory Authorities?

\section{Conspiracy Theories Linked to Coronavirus-Related Patents}

A European patent (EP3172319B1) which was filed in 2015 and is available in the public domain (European Patent Office) was circulated as 'evidence' that covid-19 was created in laboratories and was used to cause illness and deaths across the world. The patent is about attenuated coronaviruses that were patented because they showed potential to be effective vaccines against coronavirus infection. This conspiracy theory 
could be due to the misconception that a vaccine should not contain a pathogen or part of it.

Another extended version of this conspiracy theory is that a harmful coronavirus was developed in the USA, patented in 2006 and was used to infect people so that the vaccine developed in Europe (EP3172319B1) could then be used, thus creating a market for the vaccine. In fact, what was developed in the USA are nucleic acids and proteins from the Severe Acute Respiratory Syndrome (SARS) coronavirus that were patented (US2006257852) as potential vaccines for SARS (US Patent and Trademark Office), while the attenuated coronavirus vaccines developed and patented in Europe (EP3172319B1) are for avian infectious bronchitis virus (IBV), which is a coronavirus that causes disease in chicken.

\section{Some Beliefs, Prophecies or Claims Surrounding the COVID-19 Pandemic}

Since the COVID-19 pandemic affected almost all countries in the world, there were some beliefs, prophecies or unproven claims about COVID-19 that were circulated locally within specific countries, regions or continents. Thus, what may have been prominent in some geographical locations may not be so prominent or known about at all in other parts. Given below are some beliefs, prophecies and claims about COVID-19 that cropped up.

\section{Claims of Traditional Herbs or Alternative Traditional Medicines that Can Prevent or Cure Covid-19 Infections}

There were claims that some herbs or alternative medicines could prevent or cure the diseases caused by coronavirus. Some of the claims were not based on transparent and conclusive evidence apart from the word of those making the claims. However, in some countries relevant authorities took steps to dispel the claims, especially claims regarding traditional medicines to prevent or cure COVID-19 infections. For instance, in South Africa, the Traditional Healers Council warned against some traditional healers who were taking advantage of the covid-19 pandemic by claiming to be able to cure illnesses caused by covid-19 (Bramdeo, 2020).

Another example is that of the claim that an herbal concoction that includes artemisia developed in Madagascar, called COVID-Organics, could prevent or cure covid-19 infections (Tih, 2020). The evidence provided was that some few patients had recovered after being 'treated' with the herbs. Details of the sample of patients used to test the herbs and the research design are not available in the public domain.

The use of hydroxychloroquine or chloroquine with or without a secondgeneration macrolide for treating covid-19 patients before conclusive clinical trials have been completed is another example. The two drugs are generally used for treatment of malaria or autoimmune disease, and have been used and promoted for treating covid-19 patients (Pastick et al., 2020). However, no conclusive evidence for 
the benefit of the two drugs to COVID-19 patients has been demonstrated (Mehra et al., 2020), and other studies have raised concerns about serious life-threatening adverse effects that could outweigh any potential therapeutic benefits they may have (Bogaerts et al., 1996; Luca and Mihaescu, 2013).

It is therefore critical and ethical that any medicinal products (medicines or vaccines) to be used in humans, be they synthetic molecules, attenuated pathogens, parts of pathogens, traditional herbs, et cetera should undergo thorough testing in laboratories and in clinical trials before they can be licensed for wide-spread use in human beings. Properly designed research and clinical trials, as per standards set by national regulatory authorities or health ministries and by such organisations as the African Union and the WHO, are needed in order to make scientifically sound conclusions in the interest and protection of the welfare of people.

\section{Claims and Beliefs Related to Supernatural Powers}

There were some claims that were based on religious beliefs in supernatural powers. The claims were that what was referred to as COVID-19 pandemic was nothing but evil supernatural powers that could only be conquered by non-evil supernatural powers. Some religious leaders claimed to have the non-evil supernatural powers that could set people free from the clutches of the evil powers. For instance, claims and beliefs that 'holy ashes' could protect believers from the covid-19 pandemic were spread by some religious leaders in Nigeria (Lawal, 2020) and Zimbabwe (Staff Reporter, 2020). In some instances, the beliefs continued even after the religious leaders who claimed to have supernatural power to cure COVID-19 infection had died from the same infection themselves (ANA Reporter, 2020; Boorstein, 2020; Maqbool, 2020; Petersen, 2020).

\section{Some Covid-19 Prophecies}

Several religious prophets spread various prophecies about the COVID-19 pandemic. One prophecy was that the pandemic was going to miraculously disappear on 27 March 2020 after being wiped away by rain (Staff Reporter, 2020). The $27^{\text {th }}$ of March came and passed, but the pandemic did not disappear. There were also claims that the COVID-19 pandemic was the disease that was being referred to in a claimed prophecy made in 2016 when it was said that a disease worse than HIV and cancer was going to come from underneath the ocean and it was going to be brought out of the ocean by a weed, a creature in the ocean or sea food (Chirisa, 2020). No time frame for the coming of the predicted deadly disease was given when the prophecy was made in 2016.

It is a known fact that there will be diseases, epidemics and pandemics in future, and stating that fact is essentially stating something obvious and not necessarily a prophecy. Did COVID-19 come from the ocean? Was it brought out of 
the ocean by a weed, a creature or sea food? However, followers and believers of this prophecy claimed that it was COVID-19 pandemic that was predicted, and the prophet claimed that he was the only one who correctly predicted the coming of the COVID-19 pandemic and other prophets should stop claiming to have prophesied anything about the coronavirus (Munhende, 2020).

\section{Claims that the Covid-19 Pandemic is a Stage-Managed Health Crisis Propagated by} the Media and Some Powers That Be

Some people claimed that what was shown as devastating effects of COVID-19 pandemic and critical shortages of required equipment and infrastructure was a stage-managed programme aimed at creating fear and chaos for sinister purposes that varied from one version of the claim to another. The peddlers of this claim questioned why the interior of refrigerated trucks that were shown by the media were not opened for the public to see the corpses of people that had succumbed to COVID-19. One version of the claims is that what was declared to be a COVID-19 pandemic was part of geo-economical and geo-political wars between some leading countries. Another version of the claims was that the purpose of the purported stage-managed pandemic was to weaken the global economy in order to enable the powers that be to take over critical sectors of the global economies when share prices became extremely low.

\section{Belief or Claim that 'It is a disease for them not us'}

Beliefs or claims about who is susceptible to COVID-19 infections had several versions based on various differentiating characteristics which included geographical location, socio-economic class, race, religious beliefs and others. For instance, some people in some parts of the world that had not detected any COVID-19 infections claimed that the COVID-19 pandemic was not a problem for their parts of the world but for those parts that were already recording mortalities from the pandemic. Another claim was that the coronavirus pandemic was a punishment for rich countries that imposed sanctions on others (Ndebele, 2020).

In some countries, people of certain races were being perceived as the ones responsible for spreading the COVID-19 virus, leading to racial tensions and xenophobia (Anna, 2020; Tavernise and Oppel Jr, 2020; Wong, 2020). Religious beliefs also caused some people to have a sense of protection against the COVID-19 infections, and to view those who did not subscribe to the same religious beliefs not only to be vulnerable but also to be the culprits who were carrying the infection and spreading it. Socio-economic classes were also a basis for some theories, with some rich people perceiving COVID-19 infection as a disease for the poor and vice versa. 


\section{Potential Impact of Conspiracy Theories, Beliefs and Claims on Public Health Interventions}

Effectiveness of most COVID-19 prevention and treatment measures depends to a large extent on what people do as individuals. Although some community-based measures can be implemented through state of disaster or emergency laws that enable enforcement by law enforcement arms of government, at the end of the day it is what people do as individuals in their private spaces that will make a big difference in terms of disease prevention or control. For infections like COVID-19 that can spread quickly through exposure to infected people, it is critical for people who are infected or have been exposed to infection to self-isolate or be isolated from other people, including family members, and then undergo medical treatment in isolation. Through immediate isolation and treatment, the average number of people that a case infects, the effective reproductive number, $R$ (Lipsitch et al., 2003), is lowered. If $R$ is reduced to levels below 1 , then the number of cases declines until the disease outbreak comes to an end. If it is greater than 1, the number of cases increases and the pandemic spreads exponentially.

\section{Potential Negative Impact Related to Preventative Measures}

Various factors such as conspiracy theories, belief systems, unsubstantiated claims of efficacious medicines or herbs, disease explanatory models and socio-economic pressures can affect the effective reproductive number of transmission. Disease explanatory models (DEMs) are people's perceptions of a disease in terms of its etiology and its treatment or management (Kleinman, Eisenberg and Good, 1978). The DEMs influence the extent to which people believe in and make use of measures to prevent or treat the disease and are shaped by various factors that include culture, religion, beliefs, conspiracy theories and other social contexts.

Thus, conspiracy theories, beliefs and claims surrounding the COVID-19 pandemic have a bearing on people's explanatory models of COVID-19 illnesses. For example, if people believe that the COVID-19 pandemic was caused by supernatural powers such as the mark of the beast or was caused by ionizing radiation form 5G transmitters, then they may not wash hands regularly, practice social distancing, use personal protective equipment, go for screening or testing, and stay in isolation even if they are supposed to. The conspiracy theory that people will be injected with a vaccine that contains a chip with the number of the beast (triple six) could hamper vaccination programmes as and when an efficacious vaccine against COVID-19 is eventually developed and licensed for use.

Rumors and conspiracy theories have been reported to hamper public health programmes such as vaccinations. For instance, in 2003 in Nigeria the Global Polio Eradication Initiative, a programme jointly initiated by the World Health 
Organisation (WHO), the United Nations Children's Fund (UNICEF), Rotary International, US Centres for Disease Control (CDC) and national governments, faced challenges when five states in the northern part of the country boycotted oral polio vaccine because they believed that it was not safe (Yahya, 2007). The boycott was due to community beliefs that the polio vaccine was deliberately contaminated with antifertility content and HIV virus, leading to political and religious leaders deciding to officially boycott the vaccination campaign. This was in spite of the fact that the polio vaccine was used in many other countries without any major cases of serious side effects being experienced. Due to the boycott, polio remained endemic to Nigeria while it was almost eradicated in other parts of the world (Ghinai et al., 2013).

\section{Potential Negative Impact Related to Treatment of Infected People}

Unsubstantiated claims of efficacy of any medicines put the lives of innocent people at risk since they may believe in the claims and make use of the unsubstantiated medicines instead of proven medicines. People at the highest risk are economically disadvantaged people since most of the unsubstantiated medicines tend to be offered freely or at very low prices that are affordable to the poor. The peddlers of the claims may still make huge profits because of the volumes of people who buy and minimal input costs due to circumvention of stringent clinical trials for testing for efficacy in humans. If eventually it turns out that the unproven medicines do not work, the infected people would have infected others, which hinders efforts to curb the pandemic, and some innocent lives would have been lost already, which is very unethical.

\section{Need for Integrated Communication and Information Dissemination Strategies (ICIDS) to Counter Conspiracy Theories, Beliefs and Claims}

Given the huge potential of conspiracy theories, beliefs and unproven claims to compromise public health interventions and the fast speed at which they are spread, it is important to put in place well-coordinated, innovative Integrated Communication and Information Dissemination Strategies (ICIDS) to counter the rapid spread. Firstly, the ICIDS should aim to communicate effectively with specific target audiences by using methods or channels of communication that are appropriate for the target audiences and enable two-way interactive communication. Secondly, the ICIDS should package and disseminate factual information appropriately for specific target audiences. Thirdly, the communication and information dissemination should take into account and be responsive to conspiracy theories, beliefs, claims and fake news that are prevailing in the target audience. Fourthly, ICIDS should use multiple and or complementary methods of communicating and disseminating information. 
The ICIDS should be at various levels. At global level a programme could be run by such organisations as the WHO, while at continental level such organisations as the African Union and the European Union could be responsible for coordinating the continental or regional programmes. At national level, ministries in charge of health or communication could be in charge.

The ICIDS should counter and be responsive to the conspiracy theories, beliefs and unproven claims circulating in the communities and try to debunk them using proven and authentic information or facts. The ICIDS should use the same social media platforms, internet and other platforms that are used for disinformation and misinformation in order to have a strong counter effect. In addition, other means of communicating such as radio, TV, newspapers and pamphlets should also be used.

\section{References}

Achille, R., Perakslis, C. and Michael, K. (2012) ‘Ethical Issues to Consider for Microchip Implants in Humans', Ethics in Biology, Engineering and Medicine. Begell House, 3(1-3), pp. 75-86. doi:

10.1615/ethicsbiologyengmed.2013007009.

Alexandrov, M., Filyov, K., Batev, K., Nesbkov, T. and Takov, T. (2000) ‘Robotic assembling of integrated circuits applicable for SME', IFAC Proceedings Volumes. Elsevier BV, 33(20), pp. 527-531. doi: 10.1016/s1474-6670(17)381041.

ANA Reporter (2020) ‘Cameroon pastor who claimed he could cure Covid-19, dies from virus', iol, 18 May. Available at:

https://www.iol.co.za/news/africa/cameroon-pastor-who-claimed-he-couldcure-covid-19-dies-from-virus-48107319 (Accessed: 3 June 2020).

Anna, C. (2020) African nations, US decry racism against blacks in China I WDVM 25, Local DVM . Available at:

https://www.localdvm.com/health/coronavirus/african-nations-us-decryracism-against-blacks-in-china/ (Accessed: 21 May 2020).

Bogaerts, H., Capiau, C., Hauser, P., Mareschal, J. C., MéLot, V., and Simons, D. (1996) Overview of the Clinical Development of a Diphtheria-TetanusAcellular Pertussis Vaccine, The Journal of Infectious Diseases. Available at: https://academic.oup.com/jid/articleabstract/174/Supplement_3/S276/2190628 (Accessed: 22 May 2020).

Boorstein, M. (2020, 22 April.) ‘COVID-19 has killed multiple bishops and pastors within the Church of God in Christ, the nation's largest black Pentecostal denomination I News I independenttribune.com', Independent Tribune. Available at: https://www.independenttribune.com/news/covid-19-haskilled-multiple-bishops-and-pastors-within-the-church-of-god-inchrist/article_57ff84ce-6189-575f-8a00-9cac75de0ed8.html (Accessed: 3 June 
2020).

Bramdeo, A. (2020, 22 March) 'Public warned against traditional healers that claim to cure COVID-19 - SABC News - Breaking news, special reports, world, business, sport coverage of all South African current events. Africa's news leader.'SABC News. Available at: https://www.sabcnews.com/sabcnews/public-warned-against-traditionalhealers-that-claim-to-cure-covid-19/ (Accessed: 22 May 2020).

Burnard, M. and Richards, A. (2020) COVID-19 and 5G: Biggest cover-up in history? True or False? - INcontext International. Available at: https://www.incontextinternational.org/2020/04/02/covid-19-and-5gbiggest-cover-up-in-history-true-or-false/ (Accessed: 21 May 2020).

Cavanagh, D. (2007) 'Coronavirus avian infectious bronchitis virus', Veterinary Research. EDP Sciences, 38(2), pp. 281-297. doi: 10.1051/vetres:2006055.

Chirisa, S. (2020) Prophet Makandiwa Coronavirus Prophecy Which Was Made In 2016, iHarare. Available at: https://iharare.com/prophet-makandiwacoronavirus-prophecy/ (Accessed: 21 May 2020).

Farra, R., Sheppard, N. F., McCabe, L., Neer, R. M., Anderson, J. M., Santini, J. T., Cima, M. J. and Langer, R. (2012) ‘First-in-human testing of a wirelessly controlled drug delivery microchip', Science Translational Medicine. American Association for the Advancement of Science, 4(122), doi: 10.1126/scitranslmed.3003276.

Foster, K. R. and Jaeger, J. (2008) `Ethical Implications of Implantable Radiofrequency Identification (RFID) tags in humans', American Journal of Bioethics. pp. 44-48. doi: 10.1080/15265160802317966.

Ghinai, I., Willott, C., Dadari, I. and Larson, H. J. (2013) 'Listening to the rumours: What the northern Nigeria polio vaccine boycott can tell us ten years on', Global Public Health 8(10), pp. 1138-1150. doi: 10.1080/17441692.2013.859720.

Girard, M. P., Tam, J. S., Assossou, O. M. and Kieny, M. P.. (2010) 'The 2009 A (H1N1) influenza virus pandemic: A review', Vaccine. 28(31), pp. 4895-4902. doi: 10.1016/j.vaccine.2010.05.031.

Guastalegname, M. and Vallone, A. (2020) 'Could Chloroquine /Hydroxychloroquine Be Harmful in Coronavirus Disease 2019 (COVID-19) Treatment? I Clinical Infectious Diseases I Oxford Academic', Clinical Infectious Diseases. Available at: https://academic.oup.com/cid/advancearticle/doi/10.1093/cid/ciaa321/5811416 (Accessed: 23 May 2020).

Haring, J. and Perlman, S. (2001) 'Mouse hepatitis virus', Current Opinion in Microbiology. Elsevier Ltd, 4(4), pp. 462-466. doi: 10.1016/S13695274(00)00236-8.

Hilgenfeld, R. and Peiris, M. (2013) 'From SARS to MERS: 10 years of research on highly pathogenic human coronaviruses', Antiviral Research. Elsevier, 100(1), 
pp. 286-295. doi: 10.1016/j.antiviral.2013.08.015.

van der Hoek, L. (2007) 'Human Coronaviruses: What Do They Cause? - PubMed', Antiviral therapy. Available at: https://pubmed.ncbi.nlm.nih.gov/17944272/ (Accessed: 21 May 2020).

Jacob, J. (2020) 'The Upcoming 6G Technology', International Journal of Research in Engineering, Science and Management, 3(2). Available at:

https://www.ijresm.com/articles/the-upcoming-6g-technology/ (Accessed: 21 May 2020).

Kalbande, D., Haji, S. and Haji, R. (2019) '6G-Next Gen Mobile Wireless Communication Approach', in Proceedings of the 3rd International Conference on Electronics and Communication and Aerospace Technology, ICECA 2019. Institute of Electrical and Electronics Engineers Inc. doi: 10.1109/ICECA.2019.8821934.

Kilbourne, E. D. (2006) 'Influenza pandemics of the 20th century', Emerging Infectious Diseases. Centers for Disease Control and Prevention (CDC), 12(1), pp. 9-14. doi: 10.3201/eid1201.051254.

Kleinman, A., Eisenberg, L. and Good, B. (1978) ‘Culture, illness, and care. Clinical lessons from anthropologic and cross-cultural research', Annals of Internal Medicine. Ann Intern Med, 88(2), pp. 251-258. doi: 10.7326/0003-4819-88-2251.

Knapp, H., Treml, M., Schinko, A., Kolmhofer, E., Matzinger, S., Strasser, G., Lachner, R., Maurer, L. and Minichshofer, J. (2012) 'Three-channel 77 GHz automotive radar transmitter in plastic package', in Digest of Papers - IEEE Radio Frequency Integrated Circuits Symposium, pp. 119-122. doi: 10.1109/RFIC.2012.6242245.

Koch, C., Mokwa, W., Goertz, M. and Walter, P. (2008) 'First results of a study on a completely implanted retinal prosthesis in blind humans', in Proceedings of IEEE Sensors. IEEE, pp. 1237-1240. doi: 10.1109/ICSENS.2008.4716667.

Koester, C. R. (2017) The image of the beast from the land (Rev 13, 11-18): A study in incongruity. Available at: http://digitalcommons.luthersem.edu/faculty_articleshttp://digitalcommons. luthersem.edu/faculty_articles/29 (Accessed: 21 May 2020).

Lawal, S. (2020) 'What the church in Africa is doing to combat coronavirus I America Magazine', America The Jesuit Review. America Magazine. Available at: https://www.americamagazine.org/politics-society/2020/03/05/whatchurch-africa-doing-combat-coronavirus (Accessed: 21 May 2020).

Levin, M. (2017) (PDF) Towards combinatorial modeling of wireless technology generations, Russian Academy Sciences. Available at:

https://www.researchgate.net/publication/319391847_Towards_combinatori al_modeling_of_wireless_technology_generations (Accessed: 21 May 2020). 
Lipsitch, M., Cohen, T., Robins, J. M. and Ma, S. (2003) 'Transmission dynamics and control of severe acute respiratory syndrome', Science. American Association for the Advancement of Science, 300(5627), pp. 1966-1970. doi: 10.1126/science.1086616.

Luca, S. and Mihaescu, T. (2013) 'History of BCG Vaccine.', Maedica. Amaltea Medical, Editura Magister, 8(1), pp. 53-8. Available at: http://www.ncbi.nlm.nih.gov/pubmed/24023600 (Accessed: 21 May 2020).

Maqbool, A. (2020) Coronavirus: Pastor who decried 'hysteria' dies after attending Mardi Gras. BBC. Available at: https://www.bbc.com/news/world-uscanada-52157824 (Accessed: 3 June 2020).

McNulty, M. S., Bryson, D. G., Allan, G. M. and Logan, E. F. (1984) ‘Coronavirus infection of the bovine respiratory tract', Veterinary Microbiology 9(5), pp. 425-434. doi: 10.1016/0378-1135(84)90063-4.

Mehra, M. R., Desai, S. S., Ruschitzka, F. and Patel, A. N. (2020) 'Hydroxychloroquine or chloroquine with or without a macrolide for treatment of COVID-19: a multinational registry analysis. The Lancet. Available at: https://www.thelancet.com/journals/lancet/article/PIIS01406736(20)31180-6/fulltext (Accessed: 23 May 2020).

Mejova, Y. and Kalimeri, K. (2020) Advertisers Jump on Coronavirus Bandwagon: Politics, News, and Business. Available at: https://www.economist.com/china/2020/02/17/ (Accessed: 21 May 2020).

Michael, K., Michael, M. and Ip, R. (2008) 'Microchip implants for humans as unique identifiers: a case study on VeriChip', Faculty of Informatics - Papers (Archive). Available at: https://ro.uow.edu.au/infopapers/586 (Accessed: 21 May 2020).

Michael, M. G. (2010) 'Demystifying the number of the beast in the book of revelation: Examples of ancient cryptology and the interpretation of the "666" conundrum", in International Symposium on Technology and Society, Proceedings, pp. 23-41. doi: 10.1109/ISTAS.2010.5514656.

Mueller, J. and Johnson, N. (2002) 'Updating the Accounts: Global Mortality of the 1918-1920 “Spanish” Influenza Pandemic on JSTOR', The Johns Hopkins University Press, 76(1). Available at: https://www.jstor.org/stable/44446153?seq=1\#metadata_info_tab_contents (Accessed: 21 May 2020).

Munhende, L. (2020) 'Zimbabwe: Hands Off My Coronavirus, Makandiwa Says to Fellow Prophets - allAfrica.com', AllAfrica, April. Available at: https://allafrica.com/stories/202004060157.html (Accessed: 21 May 2020).

Ndebele, L. (2020, 16 April) 'Zim minister's bizarre coronavirus claim: “It's to punish the West for sanctions"', Sunday Times. Available at: https://www.timeslive.co.za/news/africa/2020-03-16-zim-ministers-bizarre- 
coronavirus-claim-its-to-punish-the-west-for-sanctions/ (Accessed: 21 May 2020).

Pastick, K. A., Okafor, E. C., Wang, F., Lofgren, S. M., Skipper, C. P., Nicol, M. R., Pullen, M. F., Rajasingham, R., McDonald, E. G., Lee, T. C. and Schwartz, I. S. (2020) 'Review: Hydroxychloroquine and Chloroquine for Treatment of SARS-CoV-2 (COVID-19) I Open Forum Infectious Diseases I Oxford Academic', Open Forum Infectious Diseases, 7(4). Available at: https://academic.oup.com/ofid/article/7/4/ofaa130/5820538 (Accessed: 23 May 2020).

Pearce, K. (2020) Pandemic simulation exercise spotlights massive preparedness gap I Hub, HUB. Available at: https://hub.jhu.edu/2019/11/06/event-201-healthsecurity/ (Accessed: 21 May 2020).

Pedersen, N. C. (2009) 'A review of feline infectious peritonitis virus infection: 1963-2008', Journal of Feline Medicine and Surgery. SAGE PublicationsSage UK: London, England, 11(4), pp. 225-258. doi: 10.1016/j.jfms.2008.09.008.

Perlman, S. and Netland, J. (2009) ‘Coronaviruses post-SARS: Update on replication and pathogenesis', Nature Reviews Microbiology. Nat Rev Microbiol, pp. 439-450. doi: 10.1038/nrmicro2147.

Petersen, C. (2020, 14 April) ‘Pastor dies from Covid-19 just weeks after holding a packed church service I You', News24. Available at: https://www.news24.com/you/news/pastor-dies-from-covid-19-just-weeksafter-holding-a-packed-church-service-20200414 (Accessed: 3 June 2020).

Psychalinos, C. and Elwakil, A. (2017) Design of CMOS Analog Integrated FractionalOrder Circuits : Georgia Tsirimokou: 9783319556321.1 st edn. Cham, Sweden: Springer International Publishing AG. Available at: https://www.bookdepository.com/Design-CMOS-Analog-IntegratedFractional-Order-Circuits-Georgia-Tsirimokou/9783319556321 (Accessed: 21 May 2020).

Reddy, M. H., Jaswanth, S. and Pramod, N. V (no date) Evolution of Mobile Networks: From 1G TO 4G. Available at: http://www.krishisanskriti.org/Publication.html (Accessed: 21 May 2020).

Sharma, P. (2013) 'Evolution of Mobile Wireless Communication Networks-1G to 5G as well as Future Prospective of Next Generation Communication Network', International Journal of Computer Science and Mobile Computing, 2(8).

Spaan, W., Cavanagh, D. and Horzinek, M. C. (1988) ‘Coronaviruses: Structure and genome expression', Journal of General Virology. J Gen Virol, 69(12), pp. 29392952. doi: 10.1099/0022-1317-69-12-2939.

Staff Reporter (2020, 11 April) 'Apostolic Sect Gives Church Members Ashes To Eat For Protection Against COVID-19 - NewZimbabwe.com', New 
Zimbabwe, Available at: https://www.newzimbabwe.com/apostolic-sectgives-church-members-ashes-to-eat-for-protection-against-covid-19/ (Accessed: 21 May 2020).

Stingl, K., Bach, M., Bartz-Schmidt, K. U., Braun, A., Bruckmann, A., Gekeler, F., Greppmaier, U., Hörtdörfer, G., Kusnyerik, A., Peters, T. and Wilhelm, B. (2013) 'Safety and efficacy of subretinal visual implants in humans: Methodological aspects', Clinical and Experimental Optometry. Clin Exp Optom, 96(1), pp. 4-13. doi: 10.1111/j.1444-0938.2012.00816.x.

Taubenberger, J. K. and Morens, D. M. (2006) '1918 Influenza: The mother of all pandemics', Emerging Infectious Diseases. Centers for Disease Control and Prevention (CDC), 12(1), pp. 15-22. doi: 10.3201/eid1209.05-0979.

Tavernise, S. and Oppel Jr, R. A. (2020) 'Spit On, Yelled At, Attacked: ChineseAmericans Fear for Their Safety - The New York Times', The New York Times, 10 April. Available at:

https://www.nytimes.com/2020/03/23/us/chinese-coronavirus-racistattacks.html (Accessed: 21 May 2020).

Tih, F. (2020) Madagascar leader urges use of supposed COVID-19 cure, Anadolu Angency. Available at: https://www.aa.com.tr/en/africa/madagascar-leaderurges-use-of-supposed-covid-19-cure/1844564\# (Accessed: 22 May 2020).

Trilla, A., Trilla, G. and Daer, C. (2008) 'The 1918 “Spanish Flu” in Spain', Clinical Infectious Diseases. Oxford University Press (OUP), 47(5), pp. 668-673. doi: $10.1086 / 590567$.

Werber, B., Baggia, A. and Znidarsic, A. (2018) 'Factors Affecting the Intentions to Use RFID Subcutaneous Microchip Implants for Healthcare Purposes in: Organizacija Volume 51 Issue 2 (2018)', Organizacija, 51(2). Available at: https://content.sciendo.com/view/journals/orga/51/2/article-p121.xml (Accessed: 21 May 2020).

WHO (2020) WHO Timeline - COVID-19, World Health Organisation. Available at: https://www.who.int/news-room/detail/27-04-2020-who-timeline-covid-19 (Accessed: 21 May 2020).

Wong, D. K. (2003) A Testimony of Jesus Christ - Volume 2: A Commentary on the Book of Revelation - Anthony Charles Garland - Google Books. Available at: https://books.google.co.za/books?id=CM7Kpr6R3JoC\&pg=PA584\&lpg=PA5 $84 \& \mathrm{dq}=$ The + Beast+from+the+Sea+in+Revelation+13+BIBLIOTHECA+SACR A-DALLAS-,+160,+337-

348\&source=bl\&ots=eKtigE0Dug\&sig=ACfU3U2600R-

dVHYzq_LT8TOhIOphapx_w\&hl=en\&sa=X\&ved=2ahUKEwinh5Hi88XpAh $X Y i 1 w K H X-x B i s Q 6 A E w A H o E C A s Q A Q \# v=$ onepage\&q=The Beast from the Sea in Revelation 13 BIBLIOTHECA SACRA-DALLAS-\%2C 160\%2C 337348\&f=false (Accessed: 21 May 2020). 
Wong, W. (2020) 'McDonald's apologizes after restaurant in China bans black people', NBC News, 17 April. Available at: https://www.nbcnews.com/news/nbcblk/mcdonald-s-apologizes-afterrestaurant-china-bans-black-people-n1184616 (Accessed: 21 May 2020).

Worldometer (2020) 'Coronavirus Cases', Worldometer. doi: 10.1101/2020.01.23.20018549V2.

Xu, Z., Shi, L., Wang, Y., Zhang, J., Huang, L., Zhang, C., Liu, S., Zhao, P., Liu, H., Zhu, L. and Tai, Y. (2020) 'Pathological findings of COVID-19 associated with acute respiratory distress syndrome', The Lancet Respiratory Medicine. Lancet Publishing Group, 8(4), pp. 420-422. doi: 10.1016/S22132600(20)30076-X.

Yahya, M. (2007) ‘Polio vaccines - "no thank you!" barriers to polio eradication in Northern Nigeria , African AFFAIRS, 106(423), pp. 185-204. Available at: https://academic.oup.com/afraf/article/106/423/185/50647 (Accessed: 21 May 2020).

YODER, M. N. (1985) 'Military Applications of GaAs Integrated Circuits', In VLSI Electronics Microstructure Science (Vol. 11) pp. 367-390. doi: 10.1016/B978-012-234111-3.50015-7. 